\title{
Lasiopogon septentrionalis, a robber fly (Diptera: Asilidae) new to the European Fauna
}

\author{
Robert A. Cannings \& Jere Kahanpää
}

\begin{abstract}
Cannings, R. A. \& Kahanpää, J.* 2013: Lasiopogon septentrionalis, a robber fly (Diptera: Asilidae) new to the European Fauna. — Entomol. Fennica 24: 113-116.

Lasiopogon septentrionalis Lehr, 1984 is recorded for the first time from Finland, and Europe as a whole. The species was previously known only from the Russian Far East. A key to the three north European Lasiopogon species is provided.

R. A. Cannings, Royal British Columbia Museum, 675 Belleville Street, Victoria, BC, V8W 9W2, Canada

J. Kahanpää (*Corresponding author), Finnish Museum of Natural History, P.O. Box 17, FI-00014 University of Helsinki, Helsinki, Finland; E-mail: jere.kahanpaa@helsinki.fi
\end{abstract}

Received 26 April 2012, accepted 16 June 2012

\section{Introduction}

Until recently, the known range of Lasiopogon septentrionalis Lehr, 1984 (Diptera: Asilidae), was confined to eastern Russia. Records (Fig. 1) span a wide range from the Lena River Basin $\left(60^{\circ} \mathrm{N} 115^{\circ} \mathrm{E}\right)$ in the west to the Kolyma Basin in the northeast $\left(65^{\circ} \mathrm{N} 155^{\circ} \mathrm{E}\right)$ and the Amur Basin in the southeast $\left(50^{\circ} \mathrm{N} 134^{\circ} \mathrm{E}\right)$ (Lehr 1984 ; Cannings, unpubl. data). This note documents the first record for Europe, a specimen collected in northern Finland, about 4,000 km to the west of the type locality on the Nyuya River in Yakutiya, the most westerly of the Russian records. Later, additional specimens confirmed the presence of a local population of $L$. septentrionalis in northern Finland.

\section{Collected specimens and collection sites}

One of us (J. K.) collected two specimens from the extreme north of Finland in 2004. A female was taken at Li: Utsjoki, Pulmankijoki $\left(69.936^{\circ} \mathrm{N}\right.$ $28.038^{\circ}$ E, see Fig. 2) on 5.VII, and a male a day later at Utsjoki, Fierranjohka $\left(69.555^{\circ} \mathrm{N}\right.$ $\left.25.889^{\circ} \mathrm{E}\right)$. The male is in the Finnish Museum of Natural History $(\mathrm{MZH})$; the female remains in Kahanpää's private collection. Dissected genitalia of the male are stored in glycerin in a microvial pinned below the specimen.

The first Finnish specimens of L. septentrionalis were caught on the banks of the Tenojoki (called Tana on the Norwegian side) and Pulmankijoki rivers. Both sites were dominated by southor west-sloping, warm sandbanks with very sparse, low vegetation. The sediment lining the shores was very fine and powdery. No other asilids were recorded at Fierranjohka; at Pulmankijoki, Lasiopogon cinctus (Fabricius, 1781) was found with $L$. septentrionalis. The sandbanks of these rivers are well known in Finland for their interesting fauna and flora. Both species were swept from ground vegetation; no further observations on behavior of the flies were made.

The presence of a local population of L. septentrionalis in Finland was confirmed two years later when Keijo Mattila, an avid Finnish amateur entomologist, collected another male and four fe- 


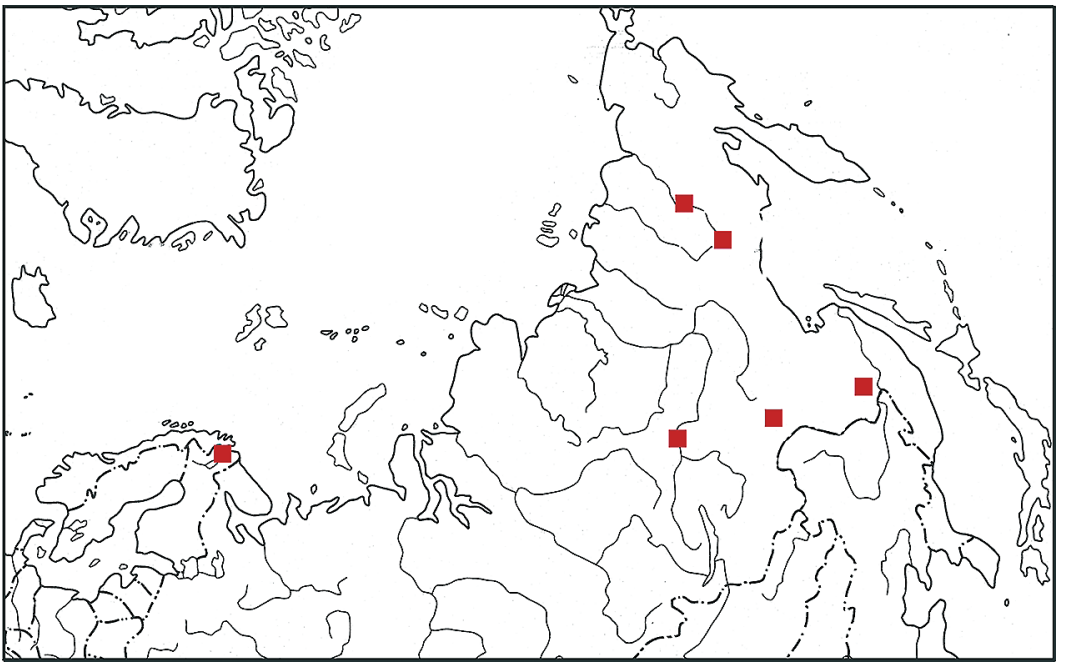

Fig. 1. Distribution of Lasiopogon septentrionalis in northern Finland and eastern Russia. males from Utsjoki, Roviniemi $\left(69.412^{\circ} \mathrm{N}\right.$ $25.827^{\circ} \mathrm{E}$ ) on $6 . \mathrm{VII} .2006$. One male L. cinctus was also found in the same area. This third location is an open sand deposit of the Teno River, similar to the nearby Fierranjohka site. These specimens are deposited in MZH and private collections in Finland (Jere Kahanpää, Helsinki; Keijo Mattila, Tampere; Antti Haarto, Mynämäki).

\section{Key to the north European Lasiopogon species}

The three north European Lasiopogon species can be separated using the following identification key, which is modified from a key to the Lasiopogon species of the eastern Palaearctic
(Cannings 2002). The striking predominance of white setae found in the Finnish specimen has not been used in the key as the amount of variation in this European population is unknown.

1. Male

- Female

4

2. Flattened disc-like lobes on dorsomedial margins of epandrium; metacoxal pegs usually present; narrow medial stripe usually present on scutum, but sometimes obscure; bristles on anteriolateral corners of abdominal tergite 1 mostly white, often with a few black; abdomen largely shining black with pale tomentum bands very narrow apically; short appressed setae on dorsum of metafemur white

L. septentrionalis Lehr

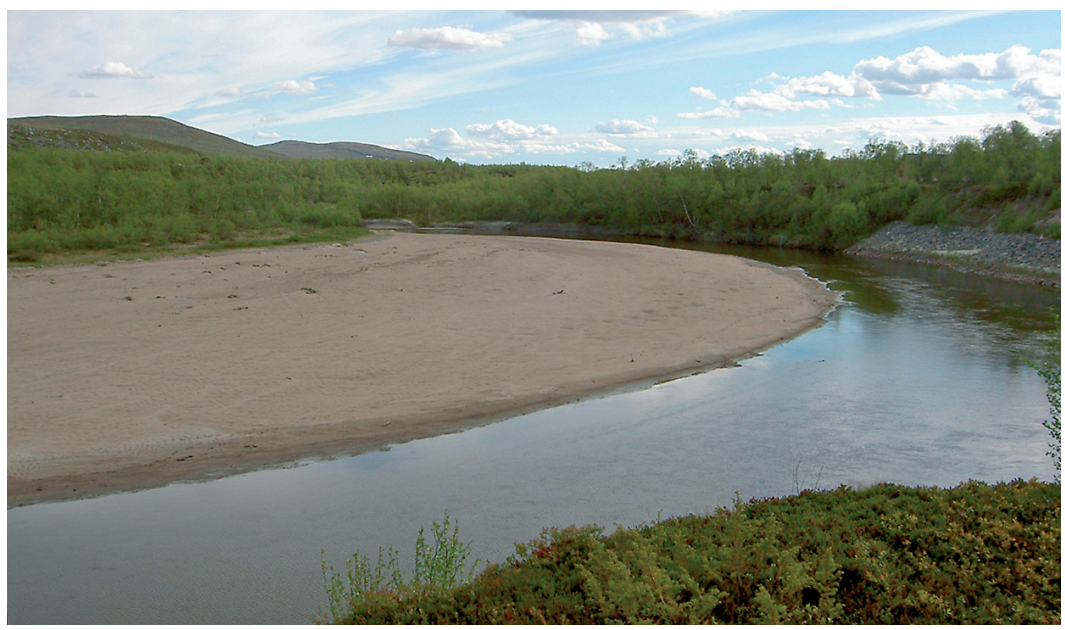

Fig. 2. Habitat of Lasiopogon septentrionalis at Pulmankijoki in northern Finland (photo by Maria Haakana, 20.VI.2004). 
- No flattened, disc-like lobes on epandrium; metacoxal pegs absent; medial stripe on scutum present or absent; bristles on abdominal segment 1 all white or white mixed with a few black; abdominal segments with pale tomentum bands variable in extent short appressed setae on dorsum of metafemur dark or white

3

3. Scutum without medial stripe; abdominal tergites almost completely shining black, the grey apical bands of tomentum covering only the intersegmental membranes; dorsal setulae white on dorsum of abdominal segments 1-2

L. hinei Cole \& Wilcox

- Scutum with medial stripe; abdominal tergites with the grey apical bands of tomentum expanded posterolaterally; dorsal setulae dark on dorsum of abdominal segments 1-2

L. cinctus (Fabricius)

4. Scutum with medial stripe, sometimes very narrow; setae on lateral lobes of sternite 8 variable

- Scutum without medial stripe; setae on lateral lobes of sternite 8 strong, dark and bristlelike; abdominal tergites largely shining black basally, any brown tomentum thin or absent; apical grey tomentum thin, but covering about half the length of the tergite, the border with the brown basal areas sometimes vague and the grey colour frequently extending basally on the midline; abdominal setae variable

\section{L. hinei Cole and Wilcox}

5. Metacoxal peg usually present; setae on lateral lobes of sternite 8 strong, dark and bristlelike; abdominal tergites shining black with a band of silver-grey tomentum narrowly covering the posterior and laterial margins; short, appressed setae on dorsum of metafemur white

L. septentrionalis Lehr

- Metacoxal peg absent; setae on lateral lobes of sternite 8 weak and pale, hardly bristlelike; abdominal tergites with band of grey tomentum covering the posterior and laterial margins, strongly expanded posterolaterally and often bordered with gold-brown tomentum; short, appressed setae on dorsum of metafemur dark, at least apically

\section{L. cinctus (Fabricius)}

\section{Discussion}

The asilid fauna of northern Finland is very species-poor. Only three widespread and common species, Lasiopogon cinctus, Choerades gilva (Linnaeus, 1758) and Rhadiurgus variabilis (Zetterstedt, 1838), have previously been recorded from the two northernmost biogeographical provinces of the country (Kahanpää, unpubl. data). The majority of Diptera material from Finnish Lapland is collected from the vicinity of a few fells (especially Saana, Malla, Pallastunturi), all near the Swedish border. Much of our knowledge of the fly fauna of the eastern parts of Lapland comes from a month-long collecting expedition to Utsjoki by R. Frey and W. Hackman in 1949 (Frey 1950). The only asilid documented in Frey's paper is L. cinctus - "from heath". He mentions that early summer 1949 was very cold and wet and thus quite unsuitable for these warmloving flies. In contrast, the weather in Finnish Lapland in early July 2004 was exceptionally hot, with afternoon peak temperatures up to $+29^{\circ} \mathrm{C}$ degrees. Strong easterly winds brought a mass migration of Aporia crataegi (Linnaeus, 1758) (Lepidoptera: Pieridae) to Lapland during the 2004 collecting period. Several other migrant butterflies and vagrants were also recorded at the same time.

In Europe, L. septentrionalis is sympatric with L. cinctus, the most common and widespread Lasiopogon species north of the Alps. The only other known congener likely to live with these two species in extreme northern Europe is L. hinei Cole and Wilcox, 1938, a fly that ranges across Eurasia to the Bering Sea and through Alaska to the Yukon and northern Alberta in Canada. Lasiopogon sibiricus Lehr, 1984 is a junior synonym of $L$. hinei (Cannings 2002). The most westerly known record of this species is in Arkangelskaya Oblast, Russia, approximately $1,000 \mathrm{~km}$ east of northern Finland (Cannings 2002).

The male genitalia of one L. septentrionalis from Finland were dissected. They are identical to those of Russian specimens. However, the Finnish specimens have more white setae in the mystax and on the katatergites than do the eastern ones (see Figs. 3-4). In fact, the mystax of all Russian specimens is completely dark. This vari- 


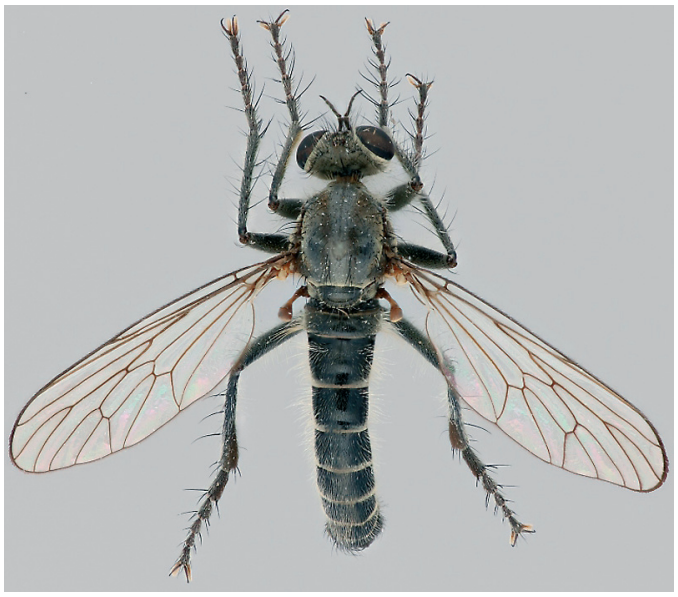

Fig. 3. Lasiopogon septentrionalis male, dorsal view. Finland, Utsjoki, Fierranjohka, 6.VII.2004. Deposited in the Finnish Museum of Natural History (MZH).

ation is not unexpected, because the colour of setae in some Lasiopogon species is often variable, and in some species with wide ranges there is a cline of setae colour. Such variation occurs also in other asilids, such as Rhadiurgus variablilis, which ranges from Scotland through Siberia and Alaska to Newfoundland. In this case the flies are considerably darker in North America than they are in Europe (Cannings 1993).

Lasiopogon septentrionalis is morphologically most similar to the Nearctic L. prima Adisoemarto, 1967 and an undescribed species from grassland stream banks in Mongolia (Cannings, unpubl. data; T. McKnight, pers. comm.). Lasiopogon prima is an Eastern Beringian species that also inhabits the edges of streams. It is distributed in Alaska and northwestern Canada (Yukon south to northern British Columbia, Alberta and Saskatchewan) (Cannings 1997, 2002).

Acknowledgements. We thank Arkady Lelej (Institute of Biology and Soil Science, Vladivostok) for confirming

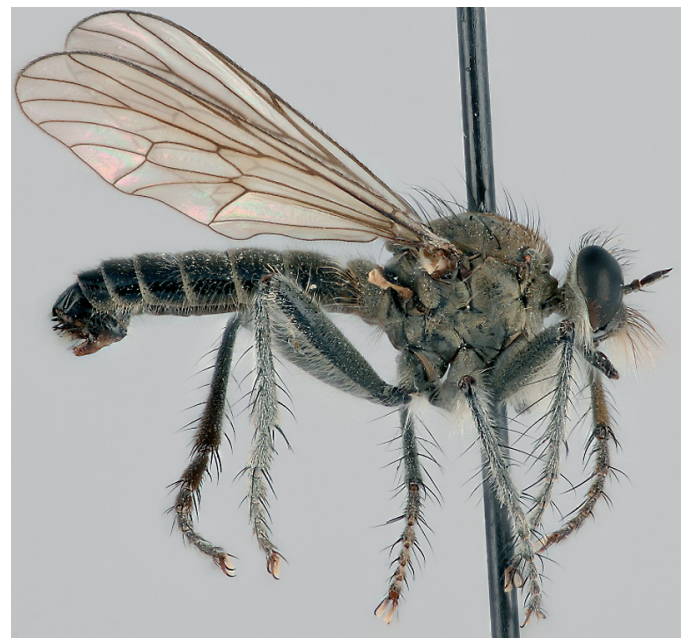

Fig. 4. Lasiopogon septentrionalis female, lateral view. Utsjoki, Pulmankijoki, 5.VII.2004. Deposited in coll. J. Kahanpää.

some of the Russian localities represented by specimens in the Vladivostok collection. Keijo Mattila supplied specimens and Maria Haakana provided the habitat photograph. Torsten Dikow made useful comments on a draft of the manuscript.

\section{References}

Cannings, R. A. 1993: New synonymy of Rhadiurgus variablis (Zetterstedt) (Diptera: Asilidae) with notes on morphology, natural history, and geographical variation. - The Canadian Entomologist 125: 337-354.

Cannings, R. A. 1997: The Robber Flies (Diptera: Asilidae) of the Yukon. - In Danks, H. V. \& Downes, J. A. (eds.), Insects of the Yukon: 637-662. Biological Survey of Canada (Terrestrial Arthropods), Ottawa. 1034 pp.

Cannings, R. A. 2002: The systematics of Lasiopogon (Diptera: Asilidae). — Royal British Columbia $\mathrm{Mu}$ seum, Victoria, BC, Canada. 354 pp.

Frey, R. 1950: Dipterafaunan vid Tana älv i Utsjoki sommaren 1949. — Notulae Entomologicae 30: 5-18.

Lehr, P. A. 1984: Assassin Flies of the tribe Stichopogonini (Diptera: Asilidae) from the fauna of the U.S.S.R. 1. —Zoologicheskii Zhurnal 63: 696-706. [In Russian.] 